\title{
PARTIÇÃO DA DEFORMAÇÃO EM REGIMES CONTRACIONAIS COM OBSTÁCULOS NO ANTEPAÍS: EXEMPLO DO SISTEMA DE FALHAS ÁGUA QUENTE, BORDA LESTE DO QUADRILÁTERO FERRÍFERO, MG
}

\section{FLÁVIO AFFONSO FERREIRA FILHO \& MARCO ANTÔNIO FONSECA}

\begin{abstract}
DEFORMATION PARTITION UNDER CONTRACTIONAL REGIMES WITH FORELAND OBSTACLES: EXAMPLE OF THE ÁGUA QUENTE FAULT SYSTEM, EASTERN BORDER OF THE IRON QUADRANGLE, MINAS GERAIS The Água Quente Fault System comprises a set of reverse/thrust faults that borders the eastern boundary of the Quadrilátero Ferrifero. The faults are responsable for thrusting of basement fragments and Archean supracrustals over Paleoproterozoic units of the Minas Supergroup. Strain partitioning under dominant constrictional regime is a particular characteristic of the fault system. Structural analysis allowed the recognition of three deformation phases that affect supracrustals of the Minas Supergroup. Phases $D_{1}$ and $D_{2}$ display ductile-brittle sets of structures whereas phase $D_{3}$ is marked by essentially brittle structures. Geometric relationships between $\mathrm{D}$-related structures (the regional cleavage $-\mathrm{S}$, and associated mineral lineation - Lmin) support the division of the fault system into structural domains in which geometry and kinematics are controlled by the presence and distance from obstacles in the foreland. Phase $\mathrm{D}_{2}$ was developed under brittle-ductile conditions. Orientation of $\mathrm{D}_{2}$ structures is strongly controlled by the previous $D_{1}$ geometry. $D_{2}$ is here interpreted as an escape tectonics due to extreme constriction that took place along fault system, caused by the presence of the Caraça structural high. In the frontal position of the obstacle, right-lateral wrench tectonics dominate whereas in the south, the distance from the structural high allowed matter to escape vertically. Presented data suggest that far from the obstacles towards the hinterland, map view of fault curvatures tend to disappear. Features indicating strain partitioning are not so obvious and must be reported through detailed mapping of the structural fabric.
\end{abstract}

Keywords: Quadrilátero Ferrífero, Água Quente System, Brasiliano Cycle

RESUMO O Sistema de Falhas Água Quente compreende um conjunto de falhas reversas e de empurrão, que está postado na borda leste do Quadrilátero Ferrífero. A Falha da Água Quente, posicionada mais a leste do sistema homônimo, é responsável pelo alçamento do Complexo Metamórfico Santa Bárbara sobre supracrustais dos supergrupos Minas e Rio das Velhas e exibe aspectos de particionamento da deformação em regime dominante de constrição, em decorrência da colisão com obstáculos no antepaís. A análise estrutural conduzida nos metassedimentos. principalmente em unidades atribuídas ao Supergrupo Minas e no embasamento arqueano, todos afetados pelo Sistema de Falhas Água Quente, permitiu registrar três fases de deformação $\mathrm{D}_{1}, \mathrm{D}_{2}, \mathrm{e} \mathrm{D}_{3}$. As fases $\mathrm{D}_{1} \mathrm{e} \mathrm{D}_{2}$ geraram uma trama dúctil a dúctil-rúptil, ao passo que a fase $\mathrm{D}_{3}$ produziu uma trama essencialmente rúptil. A fase $\mathrm{D}_{1}^{2}$ é caracterizada por uma tectônica tangencial com embasamento envolvido. As relaçōes geométricas entre os elementos da trama associada à fase $\mathrm{D}_{\text {, }}$ (relação foliação tipo xistosidade-S versus lineação mineral associada-Lmin) permitem compartimentar o Sistema de Falhas Água Quente em domínios, nos quais a geometria e cinemática do sistema são decorrentes da proximidade dos obstáculos postados no antepaís. A fase $\mathrm{D}_{2}$ é entendida como uma evolução da fase $\mathrm{D}_{1}$ (deformação progressiva), em grande parte governada pela constrição ao longo do sistema de falhas, em função do Alto Estrutural da Serra do Caraça (Maciço do Caraça). É caracterizada como uma tectônica direcional, com escape lateral no norte e vertical no sul. Estes escapes são fortemente controlados pelo arcabouço estrutural pós- $\mathrm{D}_{1}$ (boundary conditions).

Os dados apresentados permitem concluir que à medida que se afastam dos obstáculos, em direção ao pós-país, deixam de existir as feições indicativas da rotação geral das estruturass em torno dos anteparos, como por exemplo a curvatura das falhas em mapa. As evidências de particionamento da deformação são mais sutís, e foram avaliadas a partir do estudo de detalhe da trama deformacional.

Palavras-chaves: Quadrilátero Ferrífero, Sistema Água Quente, Ciclo Brasiliano

INTRODUÇĀO Fenômenos de partição da deformação têm sido cada vez mais reportados em limites tectônicos, notadamente em regimes contracionais ou de encurtamento crustal. A partição ocorre usualmente através de movimentos direcionais paralelos ao eixo do orógeno, associados a falhas reversas de vergência ortogonal ao mesmo. Exemplos de orógenos onde são reportados movimentos paralelos ao seu eixo incluem os Alpes (Mancktelow 1992), os Cárpatos (Nemcok et al. 1998) e os A palaches (Vauchez et al. 1993). Na plataforma Sul Americana, os movimentos direcionais são razoavelmente bem descritos. Tais fenômenos são causados por uma série de fatores, podendo ser listados a colisão com margens irregulares, além de processos de convergência oblíqua, dentre outros. Este último fator parece ser um dos mais comuns, ou seja, a maior parte dos orógenos naturais, de certa forma, acomoda deformação transpressional, com transporte paralelo ao seu eixo em decorrência da colisão oblíqua.

Neste trabalho, produto de tese de mestrado defendida em maio de 1999 no DEGEO-UFOP-EM em Ouro Preto, pretende-se abordar fenômenos de partição da deformação em outro contexto, especificamente aquele no qual tais processos são decorrentes da colisão com obstáculos existentes no antepaís. Muitas das feições estruturais apresentadas pelo alóctone são fortemente influenciadas pela presença de obstáculos no antepaís. Tais obstáculos, que podem se manifestar na forma de cadeias submarinas na placa em subducção, ou ainda na forma de "maciços" ou altos na placa cavalgante, produzem, em geral, rotação sistemática nas trajetórias de tensão, causando variações laterais nas trajetórias de deslocamento (Marshak 1988). Em geral, os orógenos nos quais ocorrem tais interações, mostram acentuadas curvaturas $\mathrm{cm}$ mapa, os oroclinais.

A borda leste do Quadrilátero Ferrífero, em Minas Gerais, se constitui na fração de um orógeno Neoproterozóico caracterizado pela presença de obstáculos no antepaís. Isso porque as condições de contorno (boundary conditions) que precederam o intenso retrabalhamento sofrido pela borda leste durante o evento Brasiliano, são fortemente marcadas pela ascenção de domos do embasamento, que se deu após o colapso da cadeia Transamazônica (Marshak et al. 1992, Endo 1997, Alkmim \& Marshak 1998). Tais domos influenciaram a geração de falhas, com acentuada curvatura $\mathrm{cm}$ planta, cuja existência já é reconhecida desde longa data. Neste contexto, dois sistemas principais se articulam: o Sistema de Falhas Água Quente, postado no limite leste e o Sistema Fundão- Cambotas, mais externo (Fig. 1). São os de maior expressão e que em boa parte, definem a arquitetura deste segmento do Quadrilátero Ferrífero. O denominado Sistema Fundão-Cambotas (Dorr 1969, Endo \& Fonseca 1992) mostra feições geométricas e cinemáticas, inequivocadamente provocadas pela influência exercida por obstáculos postados no antepaís. Estas feiçōes são manifestadas na forma de uma acentuada curvatura antitaxial desenvolvida em planta, pela falha mestra do sistema, com segmentos laterais com movimentos essencialmente oblíquos, marginais aos domos do embasamento (Cacté ao norte e Bação ao sul). O Sistema Água Quente (Dorr 1969) situado na zona mais interna do cinturão, por outro lado, não mostra, entretanto tais feições acentudas de curvatura, em planta, embora nos terrenos limitados pelas duas falhas mestras seja evidenciado 
particionamento da deformação pela mudança acentuada da direção dos elementos lineares em mapa, o que sugere rotação durante a deformação. A inexistência de um trabalho que descreva, do ponto de vista espacial, como se manifesta tal partição à medida que se afasta dos obstáculos, no sentido do pós-país, justifica, portanto esta contribuição. Neste sentido, ela pretende documentar a variabilidade espacial na estrutura do Sistema de Falhas Água Quente, ao longo de seu trend, onde, adicionalmente, a avaliação do acervo estrutural permitiu delinear um outro tipo de particionamento da deformação, de caráter temporal, cujas feições, em grande parte, podem ser também justificadas a partir da maior ou menor distância de obstáculos.

Em suma, a compreensão de mecanismos de partição da deformação em orógenos contracionais, a partir de colisão com obstáculos no antepaís pode, em grande valia, ser acrescida, a partir de exemplos naturais onde os obstáculos são as feições dômicas, de terrenos com arquitetura do tipo domos e quilhas (dome and keel), cuja ocorrência é típica na região do Quadrilátero Ferrífero.

QUADRO GEOLÓGICO REGIONAL O Quadrilátero Ferrílero é uma típica província de terrenos do tipo domos e quilhas (dome and $k e e l)$ cujas unidades estratigráficas registram complexa evolução durante o Arqueano e o Paleoproterozóico, com retrabalhamento parcial no Neoproterozóico (Ciclo Brasiliano). A estratigrafia regional pode ser resumida em três grandes andares (Fig. 1).

O embasamento do Supergrupo Minas é constituído por diversos complexos metamórficos. Tais complexos são usualmente períféricos as supracrustais excetuando-se o Complexo Bação, postado na região central do Quadrilátero Ferrífero. São constituídos predominantemente por gnaisses polideformados de composição tonalítica a granítica e subordinadamente por migmatitos, pegmatitos, granitos, granodioritos, anfibolitos, intrusões máficas e ultramáficas (Herz 1970).

O Supergrupo Rio das Velhas é constituído por rochas metavulcânicas e metassedimentares que caracterizam o greenstonebelt homônimo (Dorr et al. 1957) de idade arqueana (Schrank \& Souza Filho, 1998).

O Supergrupo Minas (Dorr 1969) representa uma seqüencia metassedimentar de idade paleoproterozóica (Schrank \& Souza Filho 1998) constituída por filitos, xistos, quartzitos, dolomitos e itabiritos, assentada discordantemente sobre rochas do embasamento ou do Supergrupo Rio das Velhas.
Do ponto de vista estrutural, o Quadrilátero Ferrífero é delineado por feições fortemente condicionadas pela tectônica do tipo domos c quilhas (dome and keel) que domina o padrão estrutural em mapa.

A partir de dados de diversos autores (e.g. Carneiro el al.1995, Noce 1995), uma evolução de certa forma consensual, comporta os seguintes episódios na estruturação do Quadrilátero Ferrífero: fragmentos crustais com idades de até $3,2 \mathrm{Ga}$, serviram de embasamento para o Greenstone Belt Rio das Velhas $(2,8 \mathrm{Ga}-2,7 \mathrm{Ga})$. Um evento tectônico de $2,7 \mathrm{Ga}$ a $2,6 \mathrm{Ga}$, marcado por plutonismo intermediário nas rochas do Supergrupo Rio das Velhas, definiu a arquitetura clássica destes tipos de terrenos, com domos de embasamento circundados por quilhas de rochas supracrustais.

Posteriormente, entre 2,6 Ga e 2,4 Ga a região registra o estabelecimento de uma plataforma continental de uma bacia de margem passiva, onde foram depositados os sedimentos do Supergrupo Minas. Há cerca de 2,1 Ga na região do Quadrilátero Ferrífero se desenvolveu um cinturão de falhas e dobras, com vergência para noroeste, responsável por zonas de cisalhamento de escalas regionais. Este evento tectônico não gerou foliação expressiva e teve seu início logo após a deposição dos sedimentos do Grupo Sabará, seqüência $f l y s h$ representada por turbiditos. Trata-se da Orogênese Transamazônica. O colapso orogenético da cadeia ocorreu há aproximadamente $2,095 \mathrm{Ga}$. O segundo evento de natureza compressional que afetou o Quadrilátero Ferrífero data do Brasiliano, com o desenvolvimento de um cinturão de dobras e falhas com vergência para oeste. Tal evento regenerou e deformou estruturas pretéritas, reativando intensamente a borda leste do Quadrilátero Ferrífero durante o Neoproterozóico (Alkmim \& Marshak 1998).

\section{ESTRUTURAS DA BORDA LESTE DO QUADRILÁTERO} FERRÍFERO A borda leste do Quadrilátero Ferrífero, faixa limítrofe entre o Cráton do São Francisco e a Faixa Araçuaí-Sul (Almeida 1977), tem sua estruturação condicionada aos sistemas de falhas Fundão-Cambotas e Água Quente. Nestes sistemas de falhas, inserem-se o Sinclinal Santa Rita a sul, o Homoclinal de Catas Altas a norte, o Homoclinal de Camargos e o Horst de Camargos (HiC), ambos a sul, a Nappe de Ouro Fino a sudeste, o Maciço do Caraça no centro-oeste, o Front do Fazendão, e o Domo de Santa Bárbara, a leste (Fig. 2),

O Sinclinal Santa Rita (Maxwell 1972) é caracterizado como um
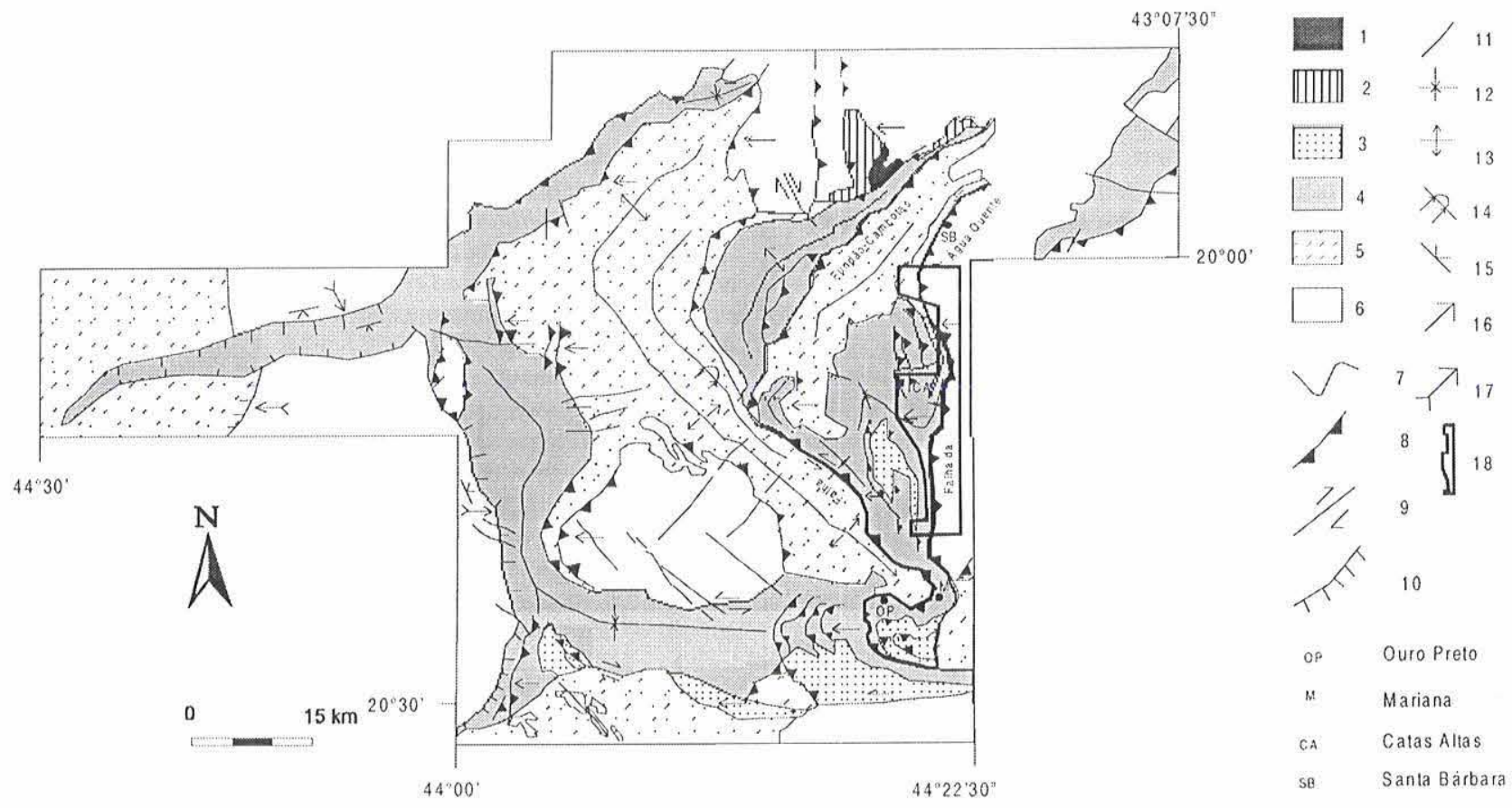

Figura I - Mapa geológico do Quadrilátero Ferrifero. 1- rochas metabásicas, 2- Supergrupo Espinhafor indiviso, 3- Grupo Itacolomi, 4- Supergrupo Minas.

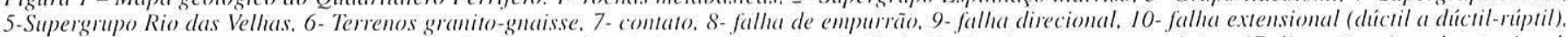
11-falha, 12-sinclinal, 13-anticlinal, 14-sinclinal invertido, 15-foliaşäo extensional. 16-indicador de transporte tectônico, 17-lineaşäo mineral extensional. 18- area investigada. Fonte: Chemale Ji: et al. 1991. 


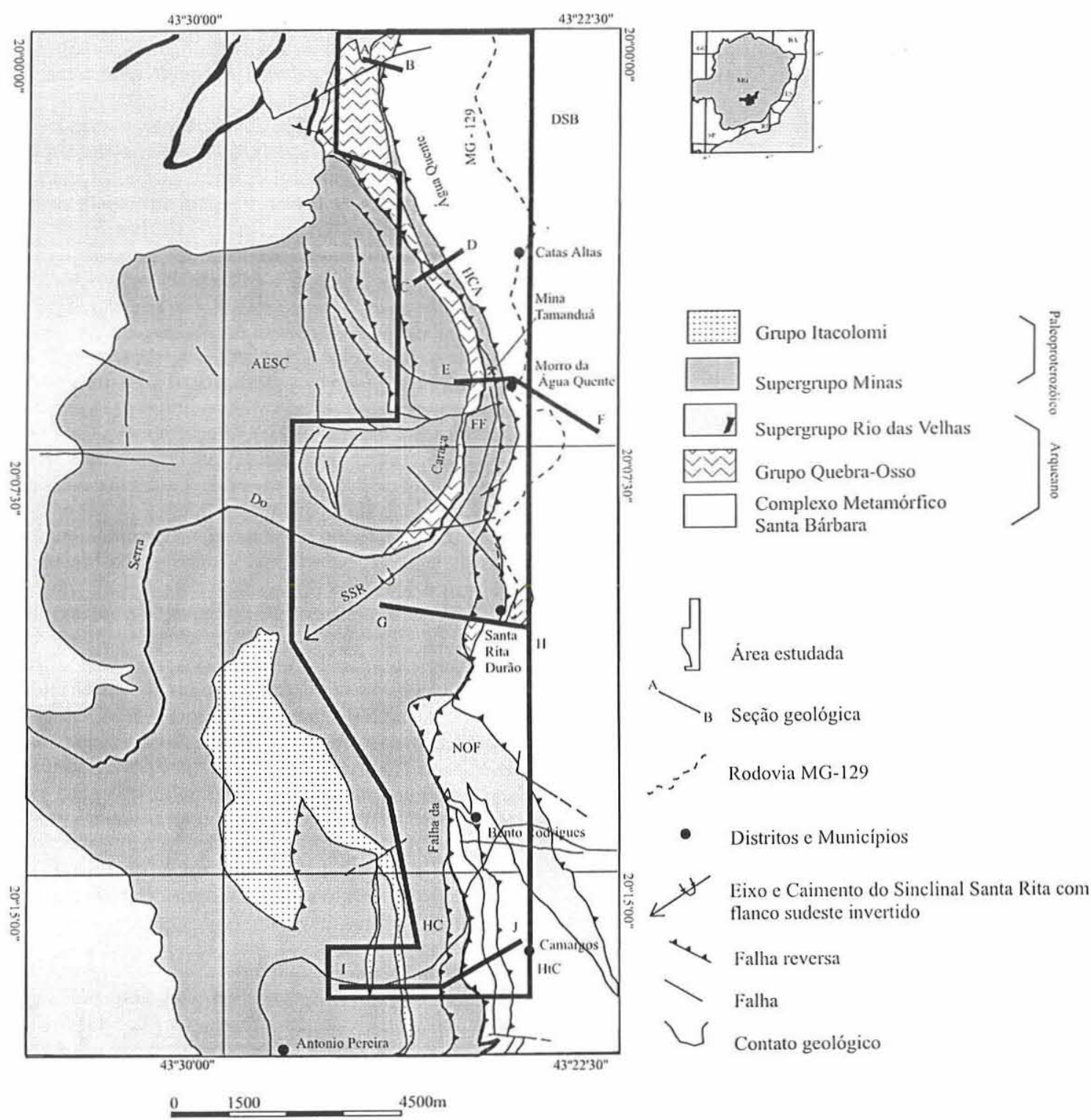

Figura 2 - Mapa geológico da borda leste do Quadrilatero Ferrifero, com as principais estruturas. SSR - Sinclinal Santa Rita, HCA - Homoclinal Catas Altas, HC - Homoclinal de Camargos. NOF - Nappe de Ouro Fino, AESC - Alto Estrutural da Serra do Caraça (Maciço do Caraça). FF - Front do Fazendão, DSB - Domo de Santa Bárbara. Fonte: Dorr 1969.

sinforme assimétrico, com traço axial de rumo norte-nordeste e nortesul, aberto no sul e apertado no norte. Os flancos são subparalelos c apresentam dobras, com a xistosidade em posição plano-axial. No flanco leste, invertido e cortado por falhas reversas com traços curvos, as unidades estratigráficas são menos espessas. No núcleo da dobra ocorrem xistos, filitos e quartzitos, todos ferruginosos e pertencentes aos grupos Piracicaba e Sabará. Contrariamente ao esperado o acamamento encontra-se com alto mergulho na região de charneira, sendo aí cortado por uma foliação, gerando uma lineação de interseção que cai para sudeste.

O Homoclinal de Catas Altas, com direção noroeste e mergulho em torno de $65^{\circ}$ para nordeste, é formado pelas rochas da base do Supergrupo Minas. O homoclinal nada mais é que a continuação para norte do flanco leste invertido do Sinclinal Santa Rita, já que o flanco oeste está omitido.

O Homoclinal de Camargos, prolongamento sul do Sinclinal Santa Rita, é caracterizado pela estratigrafia invertida e ausência do Grupo Caraça. Faz contato a leste com os gnaisses do Complexo Santa Bárbara, por falha de empurrão (Falha da Água Quente) e a oeste com as escamas de falhas de empurrão, envolvendo as rochas do Grupo Piracicaba. Constitui a estrutura de ligação entre os sistemas de falhas Fundão-Cambotas e Água Quente, adjacente ao flanco nordeste da Anticlinal de Mariana. O Horst de Camargos é formado pelos gnaisses do Complexo Santa Bárbara, a leste, com vários cordões de quartzito conglomerático do Supergrupo Rio das Velhas (Grupo Maquine).

A Nappe de Ouro Fino é uma estrutura com forma, em planta, de dobra similar com afinamento dos flancos e espessamento da charneira, envolvendo quartzitos e metaconglomerados do Grupo Maquiné (Dorr 1969, Maxwell 1972). Apresenta em seu interior faixas de gnaisses do embasamento, limitadas por falhas reversas, de direção NW, na base e zonas de cisalhamento no topo, configurando, portanto uma tectônica com embasamento envolvido.

O Alto Estrutural da Serra do Caraça é formado por quartzitos da Formação Moeda (Ribeiro Rodrigues 1992). Recebe esta denominação genética em função de estruturas que traduzem o seu comportamento de obstáculo durante o evento tectônico estruturador final da borda leste. As estruturas que caracterizam a influência do alto são: o estrangulamento do Sinclinal Santa Rita, com estruturas de escape lateral e 
vertical associadas, a foliação moldada a serra, desvios de traços de falhas e dobras apertadas e verticais, identilicadas em itabiritos junto à borda da serra, além da convergência dos traços de falhas.

O Front do Fazendão, estrutura brasiliana (Chemale Jr. et al. 1991), corresponde à descontinuidade mais a leste do Quadrilátero Ferrífero. Compreende falhamentos reversos e descolamentos, com envolvimento do embasamento. Nesta estrutura, o evento brasiliano é marcado por três fases deformacionais, sendo a fase $\mathrm{D}_{2}$, caracterizada por falhas transcorrentes próximas a E-W (Alves 1991). Os indicadores cinemáticos mostram polaridade tectônica de E para W.

O Domo de Santa Bárbara, estrutura a nordeste da área, é formado quase que exclusivamente por gnaisses. Apresenta uma foliação gnáissica de direção norte-sul, subvertical e cortada por zonas de cisalhamento espaçadas, de direção WNW, sinistrais. A lineação mineral, postada sobre a foliação gnáissica, está em posição strike e dobras indicam movimento dextral, com fluxo norte-sul.

O SISTEMA DE FALHAS ÁGUA QUENTE Este sistema envolve um conjunto de falhas, que pode ser cartografado desde o município de Mariana até Santa Bárbara, passando por Camargos, Bento Rodrigues, Santa Rita Durão, Morro da Água Quente e Catas Altas, com direção geral norte-sul (Figs. 1 e 2).

O sistema é formado por dobras de estilos e escalas variadas e falhas reversas, tendo estas traços N-S sinuosos, que possuem continuidade pela serra do Caraça (Ribeiro-Rodrigues 1992). Entretanto algumas falhas reversas ao se aproximarem da serra reorientam-se segundo a direção E-W (e.g., Falha de Alegria - Chemale Jr. et al. 1991). Sendo assim, a região ao norte de Santa Rita Durão fica caracterizada como uma zona de convergência de falhas, conforme mostram os mapas geológicos de Dorr (1969) e Maxwell (1972) para a região, c também o mapa cinemático obtido neste trabalho (Fig. 8). A vergência do sistema é para oeste e o ângulo de mergulho das falhas aumenta de sul para norte. Este sistema de fallhas é cortado por tear faults, de direções aproximadas E-W, definidas por rejeitos horizontais de comprimento variável (Maxwell 1972, Alves 1991, Ribeiro-Rodrigues 1992). Zonas de cisalhamento, de direções N-S, E-W, NW-SE, foram também mapeadas.

A falha mais a leste do sistema, Falha da Água Quente (Maxwell 1972), tem por característica estrutural sobrepor o Complexo Santa Bárbara, a leste, às rochas supracrustais, a oeste. Esta falha, ao adentrar as rochas metaultramáficas do Grupo Quebra Osso, ao norte desaparece. A cinemática desta falha varia longitudinalmente, caracterizando o fenômeno de partição da deformação. A norte e a sul, apresenta estilo geométrico e cinemático característicos de uma estrutura de rampa oblíqua sinistral ao passo que na porção central apresenta características de rampa frontal (Ferreira Filho 1999).

Dorr (1969) caracterizou a Falha da Água Quente como a extensão norte do Sistema de Falhas Dom Bosco, entendido como um conjunto de falhas postado a leste do sinclinal homônimo, que coloca, por sobre rochas do Grupo Itacolomi, sequiências atribuídas ao Supergrupo Rio das Velhas. De acordo com o autor, a falha se estende por mais de $60 \mathrm{~km}$ na direção norte-sul e possui muitas ramificações que se subdividem e se conectam novamente à falha mestra. Algumas ramificações desaparecem ao adentrar terrenos de rochas gnáissicas ou ainda se tornam falhas direcionais afetando terrenos de rochas metassedimentares. Naquela oportunidade, o autor também reconheceu a influência exercida pela Anticlinal de Mariana e pelo "Monolito do Caraça" no traçado do Sistema de Falhas Água Quente

O Sistema de Falhas Água Quente apresenta, ao longo do traço da falha homônima, importantes mineralizações de ouro, tanto $\mathrm{cm}$ veios de quartzo como em formações ferríferas (jacutinga). Estas ocorrências foram muito exploradas no passado, sendo as principais a Mina Del Rey, situada a sul do sistema próxima a cidade de Mariana e a antiga Mina da Cata Preta, localizada no segmento central do sistema, no distrito de Santa Rita Durão, Mariana-MG.

\section{MÉTODOS DE ABORDAGEM E BALIZAMENTO} GEOCRONOLÓGICO A análise estrutural realizada ao longo do Sistema de Falhas Água Quente foi executada a partir da confecção de perfis seccionando ortogonalmente o trend do sistema, que estão indi- cados na figura 2. A estrutura mesoscópica chave foi aqui designada de superfície $S_{1}$, relacionada à fase de deformação principal designada de $\mathrm{D}_{1}$. A sistemática consistiu no monitoramento contínuo desta estrutura, pois a mesma está relacionada, como envoltória, a todas as descontinuidades que existem no âmbito do sistema. $S_{1}$ é uma superfícic metamórfica, definida pela orientação planar a curviplanar de filossilicatos, especialmente de mica branca, ganhando assim o status de xistosidade. A esta superfície planar, se associam, de forma genética, uma lineação mineral (Lmin), que está postada no plano da xistosidade, além de dobras $F_{1}$, para as quais a xistosidade descrita concorre como superfície axial. As dobras descritas como $\mathrm{Z}$ foram observadas segundo o caimento de seu eixo.

$\mathrm{Na}$ área examinada, não existem dados geocronológicos disponíveis. O balizamento geocronológico foi realizado a partir da correlação estrutural para o interior do cinturão Araçuaí. Em Ribeirão do Carmo, cerca de $10 \mathrm{~km}$ a leste do sistema, um granada-clorita-muscovita xisto pertencente ao grupo Nova Lima exibe uma foliação bem desenvolvida, com direção norte-sul e mergulhos para leste. Granadas sintectônicas mostram movimento com cinemática para oeste, análoga à cinemática geral do sistema Água Quente. Uma crrócrona Sm-Nd, mostra idade de $575 \mathrm{Ma}$, em melhor ajuste (Brueckner et al. 1999). Esta foi a idade Brasiliana mais ocidental obtida no cinturão Araçuaí. Os efeitos da tectônica brasiliana têm sido monitorados bem mais para oeste, junto ao flanco ocidental do sinclinal da Moeda, ao que Alkmim \& Marshak (1998) designaram de rampa frontal do brasiliano.

Com base nas relações de superposição e cruzamento, uma segunda geração de estruturas foi ainda caracterizada. Esta segunda geração, cnglobada numa fase $D_{2}$, envolve uma foliação $S_{2}$, caracterizada como uma clivagem de crenulação, zonas de cisalhamento direcionais subverticalizadas de direção aproximada E-W, em geral dextrais, dobras $\mathrm{F}_{2}$, além de lineações de crenulação. Essas estruturas deformam os elementos estruturais da primeira fase. Foram inseridas numa segunda fase pois representam o continuar da fase $\mathrm{D}_{1}$. Em outras palavras, a nucleação das estruturas da fase $\mathrm{D}_{2}$, se ajusta às condições de contorno pós- $D_{1}$. Assim, geometria e cinemática dessas estruturas variam em função da geometria original construída pela fase $D_{1}$. Essas duas fases podem assim englobar um evento deformacional $\mathrm{E}_{1}$ que foi estruturador do sistema, ou seja, aquele que produziu o quadro deformacional finito atual, reunindo um acervo estrutural de caráter eminentemente dúctil.

Relações de cruzamento permitem detectar ainda elementos atribuídos a uma terceira fase de deformação. Ela é principalmente representada por uma foliação $\mathrm{S}_{3}$, caracterizada como uma clivagem espaçada cujo mergulho é principalmente para oeste. Ao longo desses planos são observados veios de quartzo que foram injetados sub-paralelamente a $\mathrm{S}_{3}$, durante a evolução estrutural da região. Esta fase é claramente posterior aos elementos arquiteturais do Sistema de Falhas Água Quente.

SEÇÕES GEOLÓGICAS NO SISTEMA DE FALHAS ÁGUA QUENTE Seção geológica Pedreira I (Perfil A-B) Esta seção geológica localiza-se na porção norte do sistema. As unidades litoestratigráficas presentes são o Complexo Santa Bárbara a leste, o Grupo Caraça e o Grupo Quebra-Osso a oeste (Fig. 3).

O acamamento $\left(\mathrm{S}_{0}\right)$ somente é discernível nos quartzitos do Grupo Caraça pelos horizontes metaconglomeráticos. Quando observado, está paralelo à xistosidade $\left(\mathrm{S}_{1}\right)$.

A xistosidade $\left(S_{1}\right)$ tem direção geral NNW e forte mergulho para ENE (Fig. 3, diagrama a). É caracterizada nos gnaisses pelo arranjo dos minerais micáceos em níveis que formam o bandamento gnáissico, retratando o paralelismo dessas estruturas. Adquire um padrão anastomosado nos talco-xistos, sofrendo também mudanças de direção.

As zonas de contato, tanto basal como de topo, do pacote de quartzito, são caracterizadas pela fina granulometria da rocha, com desenvolvimento da foliação milonítica (aqui designada por $\mathrm{Sm}_{1}$ ), paralela à xistosidade. Esta foliação é interpretada como uma estrutura evoluída a partir da xistosidade $\mathrm{S}_{1}$, em zonas de maior magnitude de deformação. Na zona do contato basal dos quartzitos, a foliação milonítica está associada à colocação do complexo metamórfico sobre 

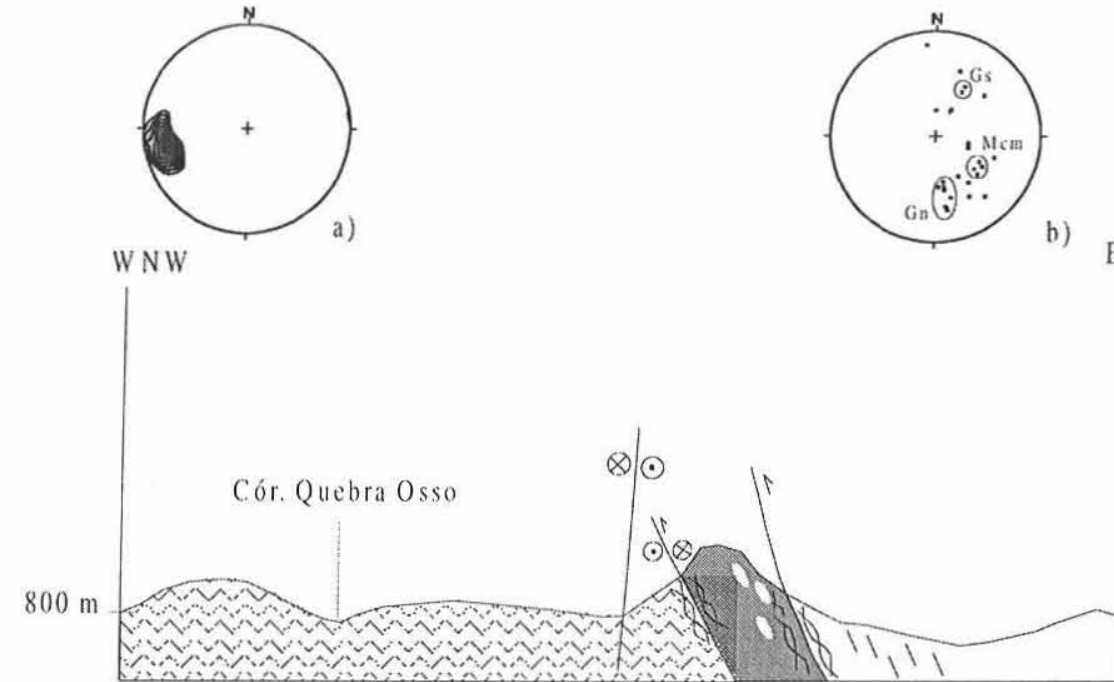

A

Quartzito com metaconglomerado polimítico na base (Grupo Caraça-M cm)

Talco-xisto (Grupo Quebra Osso-Gs)

Gnaisse (Complexo Santa Bárbara-Gn)

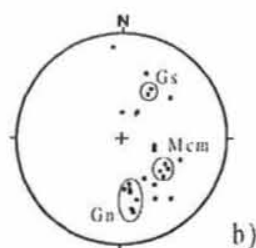

ESE
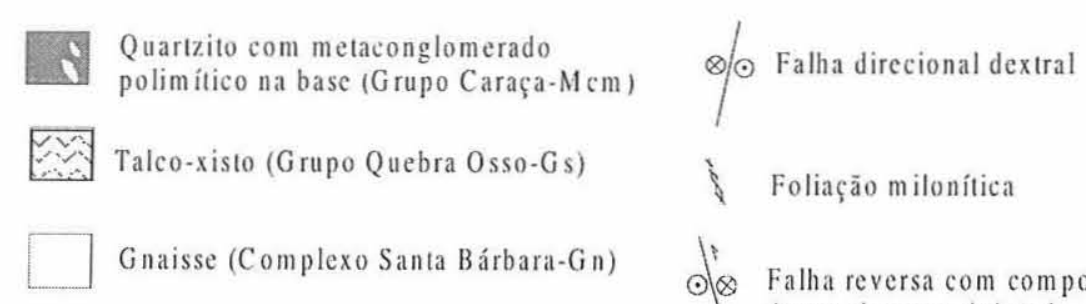

Foliação milonítica
0

B

Xistosidade (S1)

Falha reversa

$\odot \otimes$

Falha reversa com componente

de movimento sinistral

Figura 3 - Seção geológica Pedreira l, norte da região. Diagrama a: xistosidade, 74 medidas, máx.: 76/67; diagrama b: lineaçäo mineral, 27 medidas, máxs.: $171 / 51,125 / 48,26 / 68$.

as rochas supracrustais, por falhamento reverso.

A lineação mineral $\left(\operatorname{Lmin}_{1}\right)$, definida pela orientação linear dos minerais micáceos no plano da xistosidade, apresenta uma grande variação de atitude, conforme a rocha em que está hospedada. Os máximos das lineações com caimento para nordeste foram tomados em komatítos do Grupo Quebra Osso (Gs). As norte-sul foram tomadas nos gnaisses no Complexo Santa Bárbara $(\mathrm{Gn}) \mathrm{e}$ as sudeste nas rochas supracrustais do Supergrupo Minas (Mcm), denotando uma obliqüidade da lineação mineral, em relação à xistosidade de aproximadamente $60^{\circ}$ (Fig. 3, diagrama b). Decorrem daí duas observações importantes: a incongruência entre os arcabouços dos Supergrupos Minas e Rio das Velhas, e destes com o do embasamento, onde os dados parecem indicar uma componente fortemente transcorrente e a possibilidade de existir um evento mais antigo, restrito ao Supergrupo Rio das Velhas, com vetor de transporte de NE para SW, conforme sugerido por Endo et al., (1996).

Um fenômeno importante é o posicionamento das charneiras das dobras $F_{1}$ em posição sub-paralela à lineação mineral. Este fenômeno é comum em outras seções descritas a seguir, bem como em toda a borda leste.

Com base nas indicações cinemáticas, que mostram movimento de leste para oeste, caracteriza-se portanto regime oblíquo sinistral para o sistema, durante a primeira fase de deformação $\left(D_{1}\right)$, nesta seção.

Para o embasamento do Supergrupo Minas, a história estrutural é mais complexa. A lineação mineral ( $\left.\operatorname{Lmin}_{1}\right)$ cai $50^{\circ}$ para sul, enquanto que a foliação gnáissica tem direção norte-sul e está vertical. Os indicadores cinemáticos encontrados foram dobras apresentando assimetria em $\mathrm{Z}$ e eixos $b_{1}$ verticais. Estas dobras, aliadas à baixa obliquuidade da lineação mineral, caracterizam um evento deformacional e/ou estruturador direcional dextral, sofrido pelo embasamento. A cinemática deste evento não é compatível com aquela indicada pelas estruturas da fase $\mathrm{D}_{1}$, embora o embasamento também esteja envolvido naquela fase. Sendo assim, reforça-se a proposta de um evento anterior de natureza direcional, responsável pela estruturação do embasamento, conforme já sugerido por Endo et al.

\section{(1996) e Endo (1997).}

Seção geológica Catas Altas (Perfil C-D) As unidades estratigráficas observadas nesta seção são o embasamento, representado pelo Complexo Santa Bárbara a leste, as rochas da base do Supergrupo Minas (Grupo Caraça e Itabira), grupos Quebra Osso e Nova Lima, na porção central e os quartzitos da serra do Caraça, Grupo Caraça a oeste (Fig. 4). Estas unidades têm trend NW e formam o Homoclinal de Catas Altas.

$\mathrm{O}$ acamamento $\left(\mathrm{S}_{0}\right)$ está horizontal no alto da serra do Caraça, no pico do Horizonte. Em direção ao leste, inflete tomando uma posição subvertical no contato com os talco-xistos, paralelizando-se à xistosidade (Fig. 4). O paralelismo entre o acamamento e a xistosidade também pode ser constatado na serra da Boa Vista (flanco leste da serra do Caraça), onde os níveis metaconglomeráticos dos quartzitos e o bandamento dos itabiritos são paralelos à xistosidade.

As mesodobras $\mathrm{F}_{\text {, }}$ descritas em itabiritos são isoclinais, verticais, com a xistosidade em posição plano axial. As charneiras destas dobras (b) mostram variados ângulos de caimento (Fig. 4, diagrama a), porém com tendência para SE. Ocorrem em zonas de cisalhamento métricas paralelas a direção dos itabiritos e mostram uma morfologia em Z. Foram observadas, em quartzitos e itabiritos também na borda da serra, dobras intrafoliais, em bainha e isoclinais, com xistosidade plano axial. Eixos de dobras $F_{\text {}}$ sub-horizontais foram encontrados em rochas do Supergrupo Rio das Velhas.

A xistosidade ( $\left.\mathrm{S}_{1}\right)$, tem direção NW e está subvertical, com merguIho em geral para ENE, mostrando dispersão de atitudes para WSW (Fig. 4, diagrama c). Nos talco-xistos, esta xistosidade encontra-se dobrada em padrão complexo, sem direção preferencial. O contato entre o itabirito e o talco-xisto é feito segundo a xistosidade, com ocorrência de hematita compacta. Na borda da serra do Caraça, em quartzitos, a lineação mineral ocupa a posição de maior declividade (rake) no plano de $\mathrm{S}_{1}$. Neste local a lineação mineral tem caimento para sudeste (Fig. 4, diagrama b). Os quartzitos da serra da Boa Vista apresentam estruturas $S-C$ que indicam movimento reverso sinistral. Sendo assim fica caracterizada a geometria em rampa oblíqua sinistral 

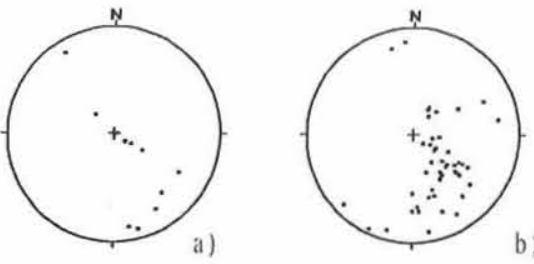

W SW
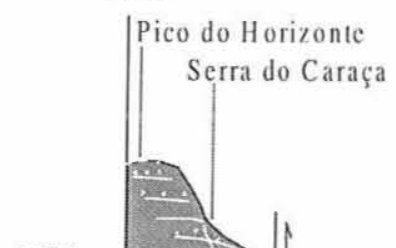

b)

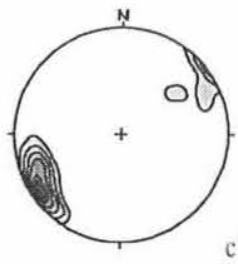

c)

ENE

1200

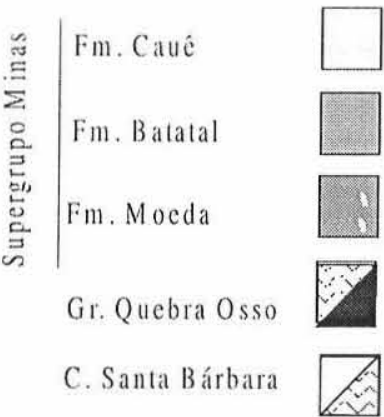

Itabirito

$1 / x$ istosidade (SI)

Filito

Quartzito sericitico, com cianita e

${ }^{0} 1$

Falha de empurrão sinistral

níveis metaconglomeráticos

Actinolita-dolomita-talco-xisto, sulfetado $x$ veio de quartzo

Falha de empurrăo

Gnaisse, biotita-clorita- $x$ isto

Acamamento $(\mathrm{SO})$

Figura 4-Seção geológica Catas Altas. Diagrama a: eixos de dobras FI. 15 medidas; diagrama b: lineação mineral, 50 medidas, máx.: $129 / 52$; diagrama c: xistosidade, 147 medidas, máx.: 56/81.

para o sistema nesta seção geológica.

Nesta seção, ocorre também o fenômeno do paralelismo entre as charneiras $b_{1}$ e a lineação mineral, ambas com rumo e caimento para SE.

Ocorre nos talco-xistos do Grupo Quebra Osso, uma lineação de intersecção entre o bandamento, possivelmente o acamamento $\left(\mathrm{S}_{0}\right)$, c a xistosidade $\left(S_{1}\right)$, com valores de: $97 / 12,85 / 7$, caracterizando o não paralelismo entre bandamento e xistosidade para as rochas desta unidade nesta seção. Reforça assim a hipótese de um evento pretérito, já visto para o embasamento e para o Supergrupo Rio das Velhas. A foliação $S_{3}$, caracterizada como uma clivagem espaçada, tem vergência para leste. Quando observada em itabiritos, retrata uma ondulação com quebra na zona de charneira, muito semelhante à estrutura extensional crenulation cleavage (ECC) (Platt \& Vissers 1980) em mesoescala. Alguns destes planos encontram-se preenchidos por quartzo, formando veios camadas.

\section{Seção geológica Morro da Água Quente (Perfil E-F)} Esta seção geológica localiza-se no centro-norte da região, em local denominado Morro da Água Quente, devido à existência de poço com águas termais. As unidades estratigráficas presentes são o embasamento, a base e a porção média do Supergrupo Minas e o Grupo Quebra Osso, base do Supergrupo Rio das Velhas (Figura 5), com o perfil passando pelo estrangulamento do Sinclinal Santa Rita, região limite com o Homoclinal de Catas Altas.

Os gnaisses do Complexo Metamórfico Santa Bárbara estão extremamente intemperizados, mostrando cores amarelas e rosas. Contêm material preto alterado, provavelmente manganês, ao longo de planos de fraturas. A mineralogia é formada por quartzo, micas, feldspato e grande quantidade de caulinita. Veios de quartzo decimétricos, tabulares, friáveis, são comuns. Estes veios são concordantes com a foliação gnáissica. Dentro dos gnaisses ocorrem lascas de talco-xisto, possivelmente milonitos (Ribeiro Rodrigues 1992) e de quartzitos.

As rochas do Supergrupo Rio das Velhas são dolomita-talco-xistos esverdeados. São cortados por diques turmalinizados muito alterados e argilosos. O quartzito da Formação Moeda é muito fino, branco a amarelado e muitas vezes esverdeado, com horizontes metaconglomeráticos. Os minerais constituintes são sericita, clorita, quartzo e turmalina preta. No contato com os filitos da Formação Batatal, os quartzitos encontram-se milonitizados, com granulometria muito fina. O filito tem coloração ocre, está alterado e é macio. $\mathrm{O}$ itabirito é especularítico e tem melhores exposiçōes nas minas de ferro, entre elas a mina de Tamanduá, indicada na seção geológica. Neste local, o seu contato basal se faz com o filito da Formação Batatal, que por sua vez está sobre os quartzitos da Formação Moeda, caracterizando o flanco normal do Sinclinal Santa Rita (Figura 5).

$\mathrm{O}$ acamamento $\left(\mathrm{S}_{0}\right)$ é caracterizado nos quartzitos da serra do Caraça pela variação composicional entre quartzo e níveis pelíticos. No alto da serra, o acamamento encontra-se horizontal e conforme aproxima-se do contato com os xistos, passa a subverticalidade.

A xistosidade $\left(\mathrm{S}_{1}\right)$ tem direção NNW e mergulho para ENE (Figura 5, diagrama a). Entretanto, localmente, apresenta mergulhos para WSW, sugerindo desta forma possíveis geometrias em leque. A xistosidade está paralela ao acamamento nas rochas do Supergrupo 


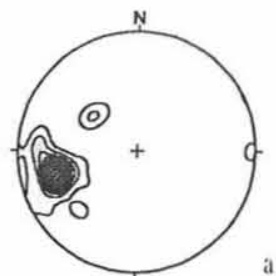

a)

W N W

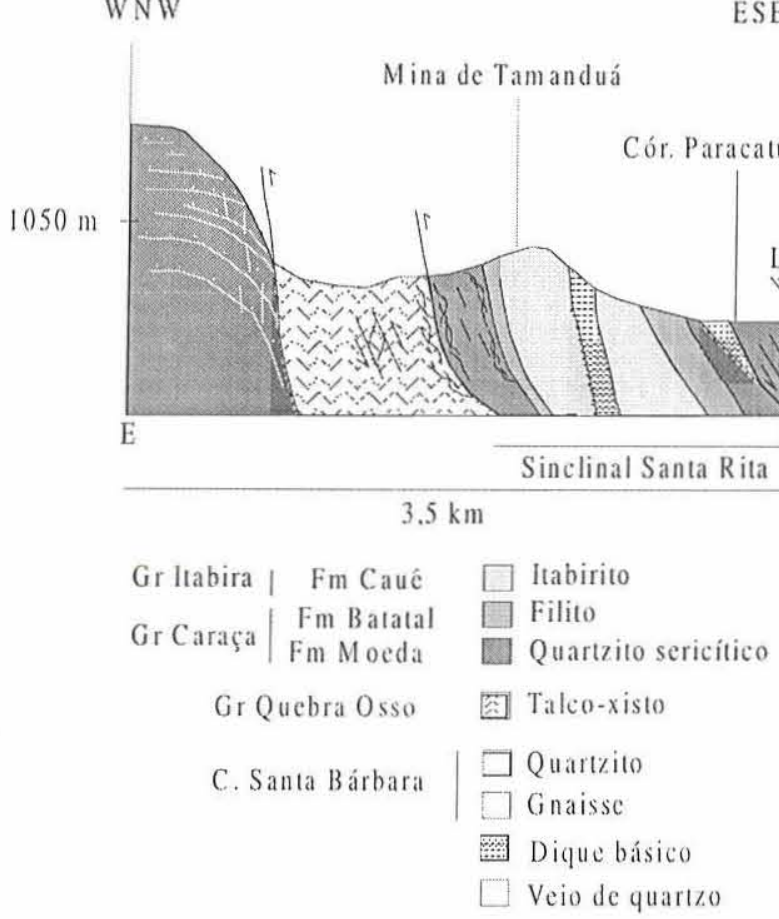

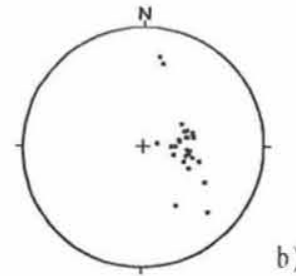

SE NW

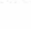
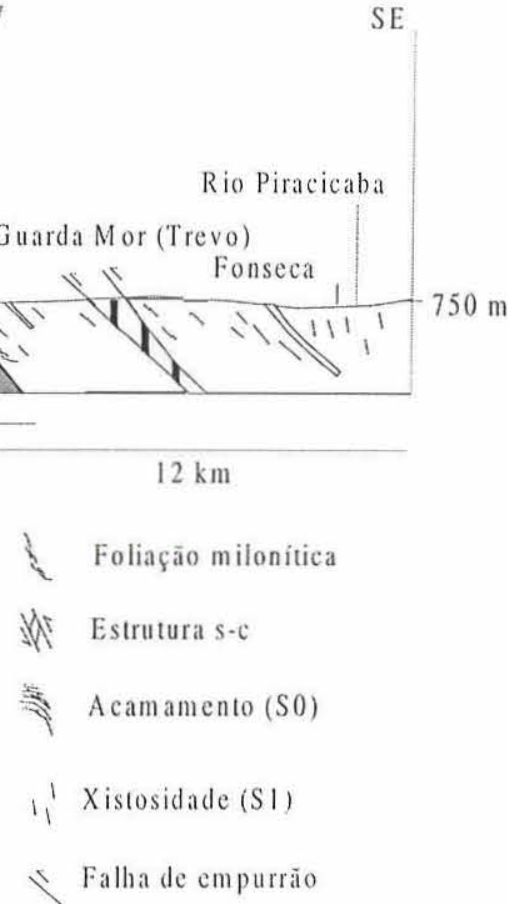

Figura 5 - Seção geológica Morro da Água Quente, diagrama a: xistosidade, 47 medidas, máx.: 73/59; diagrama b: lineação mineral, 27 medidas, máx.: 85/ 61.

Minas. Este paralelismo não ocorre nos quartzitos da serra do Caraça.

A lineação mineral ( $\left.\operatorname{Lmin}_{1}\right)$ tem caimento para leste (Figura 5, diagrama b). Em geral, esta lineação ocupa a posição de maior declividade no plano da xistosidade, caracterizando o Front do Fazendão (Chemale Jr. et al. 1991).

Em relação ao norte da área, a lineação mineral mudou de rumo de SE para E e consequentemente, a obliqüidade no plano da xistosidade. Estas estruturas pertencem a primeira família e os indicadores cinemáticos encontrados são estruturas $S$ - $C$, mostrando movimento reverso para oeste, sendo bem descritos em quartzitos milonitizados às margens do córrego Paracatu.

As dobras $F_{1}$ são isoclinais, decimétricas, com foliação plano axial e ocorrem em zonas de cisalhamento paralelas a direção das camadas. Estas dobras têm eixos paralelos a lineação mineral e com caimentos para sudeste. Apresentam uma morfologia em S, quando observadas nas zonas de cisalhamento, paralelas à xistosidade, na mina do Tamanduá. Esta geometria das dobras posiciona a mina do Tamanduá no flanco normal do Sinclinal Santa Rita (Figura 5) que aí tem traço axial NS.

A segunda geração de estruturas pode ser observada no córrego Paracatu, quando este cruza os quartzitos milonitizados, próximos ao contato com o embasamento, em Morro da Água Quente. É formada por dobras $\mathrm{F}_{2}$, reclinadas e com morfologia $\mathrm{em} \mathrm{Z}$, da foliação milonítica, dentro de zonas de cisalhamento dextrais métricas, com direção N-S, isto é, paralelas à xistosidade. Estas dobras são centimétricas a decimétricas. As charneiras das dobras $\mathrm{F}_{2}$ estão inclinadas em alto ângulo, e rumam para leste, sentido de mergulho da xistosidade, caracterizando assim dobras reclinadas (McClay 1987). Tais dobras refletem um regime direcional, transcorrente dextral, com direção norte-sul.
Seção geológica Santa Rita Durão ( Perfil G-H) A seção gcológica (Perfil G-H) vai da antiga mina de ouro da Cata Preta até o rio Piracicaba (Fig. 6).

$\mathrm{O}$ acamamento $\left(\mathrm{S}_{0}\right)$, definido por variações composicionais e granulométricas, é muito bem caracterizado nas rochas do Supergrupo Minas. Possui direção NE e mergulho para sudeste (Fig. 6, diagrama a).

As rochas compõem o Homoclinal da Cata Preta (Fig. 6), estrutura local e definida pelo acamamento paralelo à xistosidade, com direção NNE e mergulho em torno de $45^{\circ}$ para ESE. Este homoclinal é um segmento do flanco leste invertido do Sinclinal Santa Rita.

A xistosidade $\left(S_{1}\right)$ tem direção NE e mergulha para SE (Fig. 6, diagrama b). Mostra um paralelismo com o acamamento. Enquanto acamamento e xistosidade estão paralelizados nos flancos do sinclinal. esta relação se mantém no núcleo, exceto $\mathrm{em}$ zonas de dobras mesoscópicas $\mathrm{F}_{1}$. Estas possuem charneiras que rumam para ESE (Fig. 6 , diagrama d), com lineações de interseção $\mathrm{S}_{0} \times \mathrm{S}_{1}$ no mesmo sentido, caracterizando também dobras reclinadas. Outro aspecto relevante é que, contrariamente ao esperado, na calha do sinclinal o acamamento exibe mergulhos elevados. Há que se considerar ainda o fato de que o traço axial cartográfico do Sinclinal Santa Rita, na altura da seção, é NE. Este valor é discrepante e não coincide com as mesoestruturas citadas (charneiras de dobras $\mathrm{F}_{1} \mathrm{e}$ lineação de interseção $\mathrm{S}_{0} \times \mathrm{S}_{1}$ ).

$\mathrm{O}$ fato da não coincidência entre as estruturas da fase $\mathrm{D}_{1}, e . g$. charneiras de dobras $\mathrm{F}_{\mathrm{l}}$, com a direção do traço axial cartogrático do Sinclinal Santa Rita, sugere que o mesmo seja uma estrutura pretérita ao evento $E_{1}$, conforme já indicado por Dorr (1969), Maxwell (1972) e Chemale et al. (1991). Sendo assim o evento $E_{1}$ obliterou, principalmente a borda leste, do Sinclinal Santa Rita, descaracterizando a trama das rochas que o constituem.

A lineação mineral $\left(\operatorname{Lmin}_{1}\right)$ e a lineação de estiramento de seixos, 


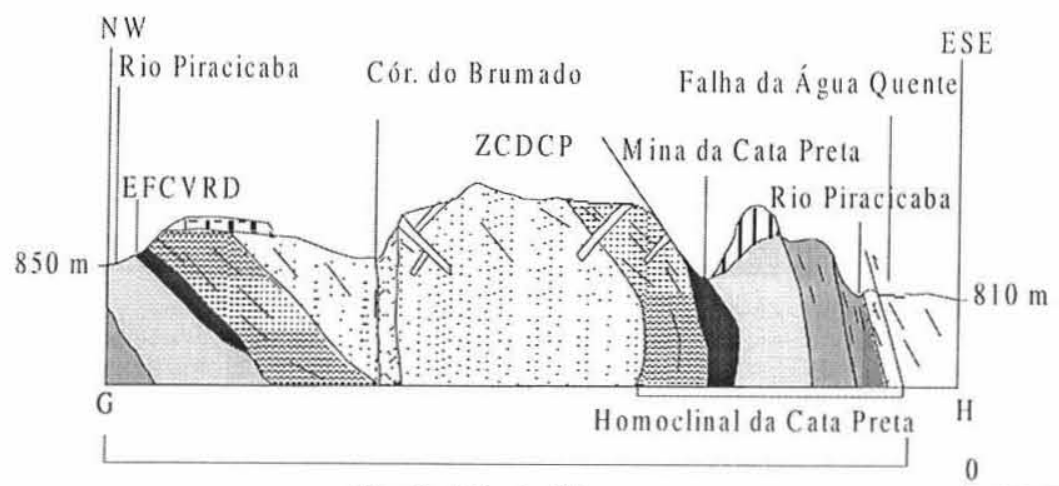

Sinclinal Santa Rita
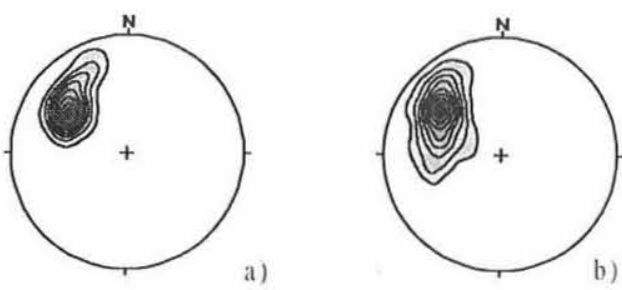

a) b)
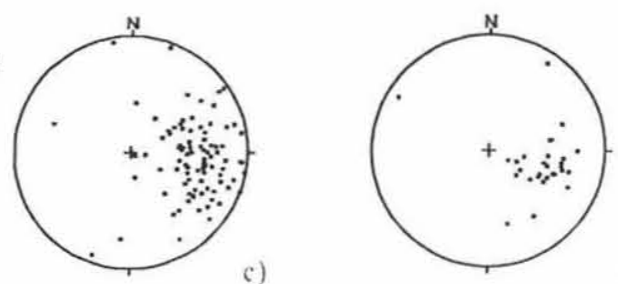

c)

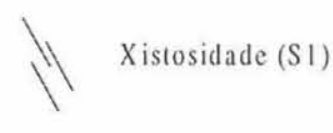

ZCDCP

Zona de cisalhamento dextral da Cata Preta

Veio camada de quartzo (S3) (espessura exagerada)

Figura 6 - Seçäo geológica Santa Rita Durão, mostrando o Sinclinal Santa Rita, com seu flanco leste invertido. Diagrama a: acamamento. f63 medidas, máx.: 122/50; diagrama b: xistosidade. 1283 medidas, máx.: 125/54; diagrama c: lineasão mineral. 183 medidas, máx.: $97 / 36$. diagrama d: charneiras FI. 52 medidas, máx.: 104/38.

foram englobadas no mesmo estereograma. Nele pode-se observar uma grande dispersão, variando de NE até SE (Fig. 6, diagrama c). Entretanto, se forem tomados os valores modais da lineação mineral e da xistosidade, obtêm-se um máximo da xistosidade $\mathrm{S}$, de 120/50, com a lineação mineral Lmin, em torno do rumo de $90^{\circ}$, caracterizando obliqüidade de aproximadamente $50^{\circ}-60^{\circ}$. Os indicadores cinemáticos são consistentes em indicar movimentos reversos, daí obtêm-se um quadro cinemático reverso oblíquo dextral.

As dobras da foliação $\left(b_{2}\right)$ caracterizam a segunda geração de estruturas, produto da deformação das estruturas $\mathrm{D}_{1}$. A lineação de crenulação $\left(\mathrm{Lc}_{2}\right)$ ocupa aproximadamente a posição norte-sul, no plano de $S_{1}$, em baixo ângulo. $S_{2}$ é uma clivagem de crenulação. O máximo de $\mathrm{S}_{2}$, corresponde a um plano que mergulha para $\mathrm{SE}$, isto é, a vergência de $\mathrm{S}_{2}$ também é para oeste.

Seção geológica Rio Gualaxo do Norte (Perfil I-J) Esta seção foi realizada no extremo sul da área, ao longo do rio Gualaxo do Norte. Os caminhamentos utilizados foram a estrada que une Camargos a Bento Rodrigues (trecho da antiga estrada real), parte da estrada Santa Rita Durão/Mariana e o acesso, a partir dessa estrada, até a vila residencial da SAMARCO em Antônio Pereira.

Como na seção anterior, às unidades estratigráficas presentes são o embasamento, os quartzitos do Grupo Maquiné e as rochas do Supergrupo Minas, exceto a base deste, ou seja, o Grupo Caraça.

Além do envolvimento do embasamento do Supergrupo Minas na deformação e a omissão do Grupo Caraça o perfil retrata o baixo ân- gulo da xistosidade, em oposição ao norte da área, além de um conjunto de escamas de empurrão interpretadas como alóctones.

O Complexo Metamórfico Santa Bárbara, entendido como o embasamento do Supergrupo Minas, é observado na região de Camargos e é constituído por gnaisses. Os quartzitos do Grupo Maquiné são finos, foliados e contêm níveis de metaconglomerados, com seixos quartzosos. Os xistos do Grupo Nova Lima, representado como lascas de falha na seção (Figura 7), são cloríticos.

As rochas do Supergrupo Minas são itabiritos pulverulentos e quartzosos, exibindo passagem manganesífera, no contato com os quartzitos ferruginosos intercalados com filitos da Formação Cercadinho. Estes quartzitos intercalam-se, por falhas de empurrão, a clorita-xistos, possivelmente do Grupo Sabará. Filitos, densos, pretos, grafitosos, com magnetitas e agulhas de cianita, afloram nas proximidades da fazenda Gualaxo.

A xistosidade $\left(S_{1}\right)$ é penetrativa em todas as litologias e tem direção norte-sul com mergulho moderado a baixo para leste (diagrama a). A lineação de estiramento mineral (Lmin), é definida em seixos estirados nos quartzitos tem baixo caimento para leste (diagrama b) e exibe uma insignificante obliqüidade em relação à xistosidade. A lineação de interseção entre $\mathrm{S}_{0}$ e $\mathrm{S}_{1}$ tem caimento para $\mathrm{SE}$.

Os indicadores cinemáticos encontrados foram estruturas $S-C \mathrm{em}$ quartzitos no rio Gualaxo do Norte. Estas estruturas são centimétricas a decimétricas e mostram movimento reverso de leste para oeste. Nesse segmento do sistema portanto, fica caracterizado um regime essencialmente frontal, com transporte para W. 
Flávio Affonso Ferreira Filho et al.

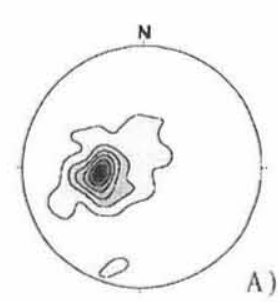

A)
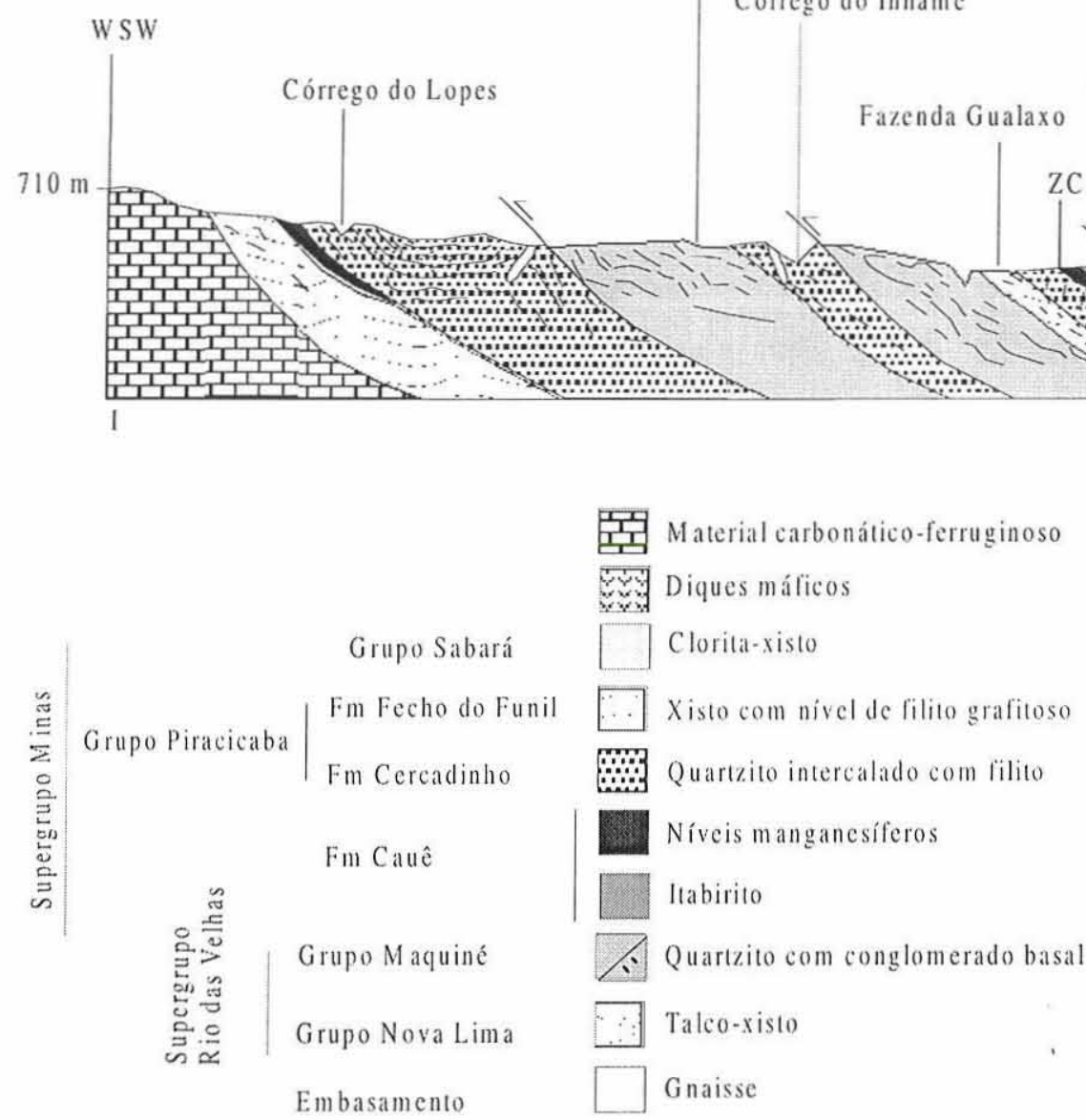

N SW
I

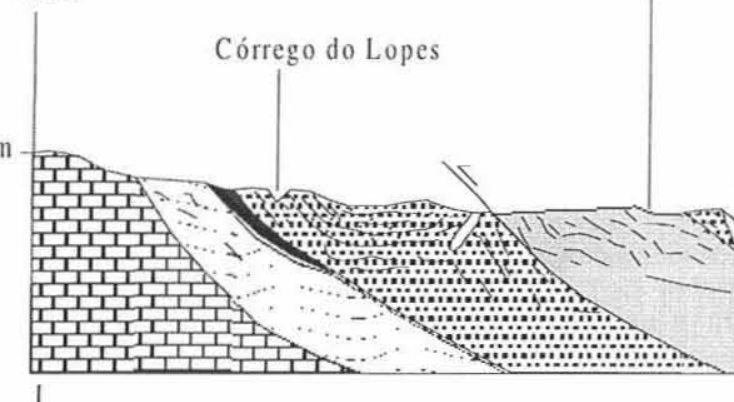

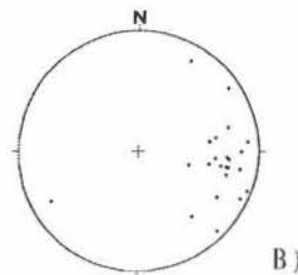

Córrego do Inhame
B)

ENE
Água da N.S Aparecida

Fazenda Gualaxo

\section{a<smiles>C1CCCCC1</smiles> 


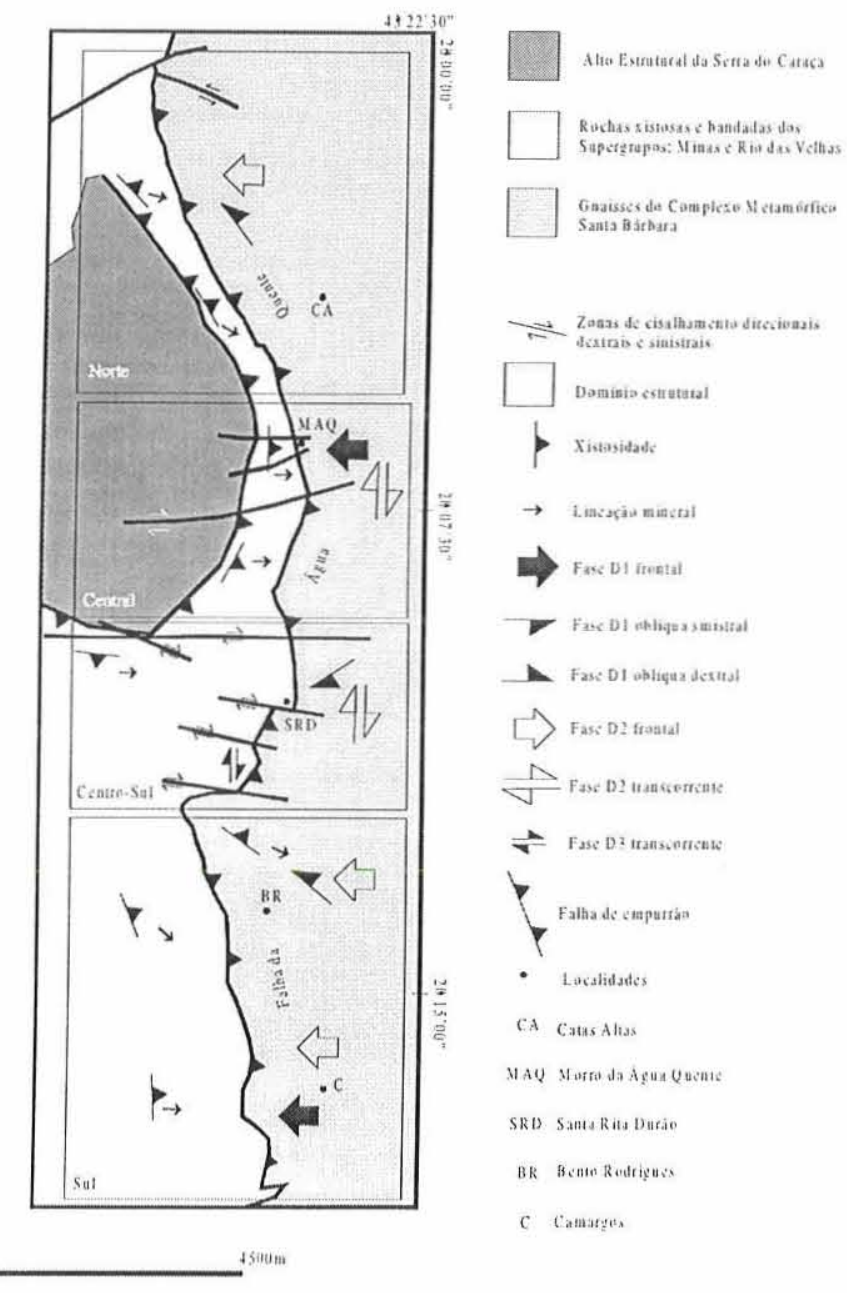

Figura 8-Esbogo estrutural-cinemánico do Sistema de Falhas Água Quente.

No segmento norte, as falhas bordejam o maciço, com rumo NW, propiciando desta forma o estabelecimento de uma tectônica tangencial com escape oblíquo, através de deslocamentos reversos sinistrais.

O segmento central (equivalente ao Front do Fazendão, de Chemale Jr. et al. 1991) é o segmento do sistema onde a tectônica tangencial é frontal, de alto ângulo, com a foliação atingindo mergulhos da ordem de $90^{\circ}$. Neste segmento, o encurtamento foi mínimo, $\mathrm{cm}$ virtude da posição frontal ao maciço, que coibiu a propagação da deformação em direção ao oeste.

A porção centro-sul corresponde ao segmento da falha onde as influências do maciço perdem expressão junto ao Sistema de Falhas da Água Quente. Isso não quer dizer que sua influência aí inexista, pois neste trecho é que fica mais evidente, em mapa, a curvatura das falhas que bordejam o maciço junto ao flanco normal do Sinclinal Santa Rita. $\mathrm{O}$ traço das falhas desenvolve forte curvatura antitaxial, que se inicia no bordo sul do maciço do Caraça com rumo aproximadamente EW e curva-se para sul, conectando-se ao flanco NE do Anticlinal de Mariana (Figura 2). Essas falhas, que se organizam em escamas sucessivas que truncam a calha e oflanco inverso do Sinclinal Santa Rita, têm sua curvatura em mapa atenuada em direção ao pós-país, até atingir certa linearidade junto ao Sistema de Falhas Água Quente propriamente dito. Neste domínio ocorre ampla dispersão da lineação mineral, e a falha opera tanto ao nível do embasamento como ao nível das supracrustais, truncando, na forma de sucessivas escamas, o flanco invertido do Sinclinal de Santa Rita. A dispersão da lineação mineral decresce para sul, com movimentos dominantemente frontais, na região de Camargos, com escamas orientadas norte-sul. As falhas possu$\mathrm{em}$ baixo ângulo, inferior a $30^{\circ}$, sugerindo desta forma, maior magnitude de encurtamento.
A tectônica de escape ou tectônica de indentação é aquela na qual há fluxo lateral em relação a um indentante ou obstáculo. Este fluxo é, $\mathrm{em}$ geral, acomodado a partir de falhas transcorrentes, e se manifesta a partir da partição da deformação em estilos estruturais diferenciados e famílias de estruturas que se sucedem no tempo. Na literatura, são bem conhecidos os exemplos de tectônica de escape, relativos a feições na escala geotectônica e também em estruturas de ordem hierárquica inferior.

A cinemática da fase $\mathrm{D}_{2}$ é estabelecida a partir do monitoramento das estruturas atribuídas à segunda fase, com a conseqüente avaliação da deformação sofrida pelos elementos da trama associada à primeira fase. Em que pesem os demais elementos associados à segunda fase, atenção especial foi dada às dobras $F_{2}$, que envolvem a superfície $S_{1}$. Isto decorre de uma razão relativamente simples: por um lado as estruturas da segunda fase não são de ocorrência generalizada e, portanto, de mais difícil monitoramento, e por outro, a análise dos estilos dos dobramentos permite deduções mais seguras a cerca do campo de tensões envolvido, já que as dobras observadas não decorrem de complexos mecanismos de dobramento, predominando o deslizamento flexural.

Dois tipos principais de dobras foram detectadas: dobras normais, de abertas a fechadas, evoluindo para dobras assimétricas, com charneiras rumando em geral na direção norte-sul e vergentes para oeste. Essas dobras, inversas ou inclinadas, são em geral flexurais de deslizamento, havendo apenas, localmente, geração de uma clivagem espaçada que é estatisticamente paralela à superfície axial das mesmas. Dobras normais são detectadas nas seções mais centrais, afetando metassedimentos do Supergrupos Minas e mesmo rochas atribuídas ao Supergrupo Rio das Velhas. Dobras com assimetria mais acentuada são detectáveis ao sul. Elas são freqüentes no segmento sul do sistema, nas regiões de Mariana e Antônio Pereira (Figura 2).

O segundo tipo de dobras exibe o mesmo padrão flexural de deslizamento, porém as dobras sc orientam em posições diametralmente opostas às primeiras. São dobras reclinadas, com charneiras rumando para E, com alto caimento. Em planta, possuem assimetria em Z Foram detectadas nas zonas frontais ao maciço do Caraça.

Os dois estilos contrastantes, representados em mapa, através da direção de máximo encurtamento são aqui interpretados como duas formas diferentes de escape (figura 8). No primeiro caso, o mais comum, trata-se de um escape vertical, onde a nucleação das dobras ocorre após o estágio de máximo encurtamento adquirido através dos sistemas de empurrão. Em outras palavras, o encurtamento imposto pelos sistemas de empurrão (estruturas descontínuas) e pelas dobras $F_{1}$ (estruturas contínuas), não foi capaz de absorver toda a deformação imposta. Nestas condições, a ausência de obstáculos ou a distância dos mesmos permitiu o fluxo de matéria na vertical que é o sentido mais natural e favorável, nestas condições, para o escape.

O segundo tipo de escape é o escape lateral, detectado nas porções frontais ao maciço do Caraça. A proximidade do obstáculo impõe uma menor magnitude do encurtamento durante a fase $\mathrm{F}_{1}$, pois as falhas são de alto ângulo, implicando assim $\mathrm{cm}$ menor translação lateral. A intensa constrição de matéria na posição frontal do obstáculo e a impossibilidade do escape vertical induz o fluxo lateral, que se manifesta a partir de um par cisalhante dextral, instalado a partir de zonas de cisalhamento normais a direção ạ cinemática.

A fase de deformação $D_{3}$ foi proposta para a região, devido ao mapeamento de estruturas discordantes e posteriores às estruturas anteriormente retratadas às fases $\mathrm{D}_{1} \mathrm{e} \mathrm{D}_{2}$. Em geral, principalmente nos domínios centro-sul e sul, estas estruturas estão preenchidas por veios de quartzo, mineralizados em ouro.

A estrutura característica desta fase de deformação é uma clivagem $\left(\mathrm{S}_{3}\right)$ com mergulho para oeste, portanto contrária a vergência do Sistema de Falhas Água Quente. Esta clivagem ora se confunde com a clivagem de crenulação $\left(S_{2}\right)$, porém é sempre discordante da xistosidade $\left(\mathrm{S}_{1}\right)$. Ocorre em praticamente toda a borda leste, sendo principalmente observada nas rochas do Supergrupo Minas, embora comum nos quartzitos do Grupo Maquiné. Nos xistos, filitos e principalmente itabiritos expressa-se como uma extension crenulation cleavage (ecc). 
Devido a esta indicação cinemática, aliada ao mergulho contrário da clivagem $\mathrm{S}_{3}$, e à estruturação pós- $\mathrm{D}_{1} / \mathrm{D}_{2}$, esta fase pode ser entendida como um relaxamento do sistema de falhas, imediatamente à fase $\mathrm{D}_{2}$, com as mesmas características cinemáticas daquela fase. Esta avaliação, entretanto fica restrita ao campo especulativo, pois os dados não são de todo conclusivos. Em primeiro lugar, foi priorizado o estudo da evolução de caráter dúctil do sistema (fases $\mathrm{D}_{1}$ e $\mathrm{D}_{2}$ ), pois as mesmas é que o estruturaram.

Por outro lado, a avaliação cinemática da fase $\mathrm{D}_{3}$ é em parte dificultada, pois as estruturas correlatas muitas vezes estão ausentes ou requerem monitoramento específico.

CONCLUSŌES A análise das estruturas tectônicas observadas $\mathrm{e}$ medidas na região afetada pelo Sistema de Falhas Água Quente sugere que a evolução cinemática deste sistema de falhas tenha evoluído através de I evento deformacional com 3 fases de deformação.

A fase de deformação $\mathrm{D}_{1}$ (tectônica tangencial), é caracterizada pelo desenvolvimento de uma proeminente xistosidade $\left(S_{1}\right)$, envoltória do sistema, que muitas vezes está paralela à superfícies axiais de dobras $\mathrm{F}_{1}$ ou evolui para uma foliação milonítica em sítios de maior magnitude de deformação, geralmente em zonas de contato litológico. Sobre esta xistosidade está postada uma lineação mineral $\left.(\operatorname{Lmin})_{1}\right)$ de rumo E-SE. A relação geométrica entre a xistosidade e a lineação mineral varia longitudinalmente ao longo do sistema, isto é, ora a lineação mineral ocupa a posição de maior declividade, ora apresenta uma forte obliqüidade em relação a xistosidade. Isto é atribuído às condições de contorno impostas pelo evento deformacional anterior. A fase $D_{1}$ representa uma tectônica tangencial com embasamento envolvido.

A fase de deformação $D_{2}$ (escape), interpretada como escape derivado da fase $\mathrm{D}_{1}$, é entendida como o continuar $\mathrm{em}$ condições de compressão máxima, surgindo então feições de escape lateral e vertical. Foi definida pela deformação da xistosidade $\left(\mathrm{S}_{1}\right)$, de diferentes maneiras, em função da posição perante os obstáculos. Dobras $\mathrm{F}_{2}$, com padrão $\mathrm{em} \mathrm{Z}$, da foliação milonítica, indicam que esta fase gerou desde transcorrências dextrais no domínio Central (escape lateral) até esforços coaxiais à fase $\mathrm{D}_{1}$, a sul do domínio Sul (escape vertical).

Uma terceira família de estruturas, rúpteis, foi suficiente para sugerir uma terceira fase de deformação. Estas estruturas são grandes planos de fratura $\left(\mathrm{S}_{3}\right)$, discordantes da xistosidade regional, com veios de quartzo, em geral mineralizados em ouro e em forma de camada. A esta fase estão associadas fraturas de tração, com a mesma geometria das fraturas, preenchidas por quartzo, que indicam movimento dextral. Isto, associado à xistosidade $\left(S_{1}\right)$, retrata uma fase extensional, final, para o sistema.

Pode-se compartimentar o Sistema de Falhas Água Quente em 4 domínios, diferenciados pelas relações geométricas entre os elementos estruturais associados à fase $\mathrm{D}_{1}$ (Figura 8).

O domínio Norte tem o traço da falha na direção NNW. Os itabiritos presentes apresentam dobras isoclinais verticais, com eixos no rumo SE, paralelos a lineação mineral. Estas dobras têm um padrão chevron, retratando uma compressão junto a um anteparo. Esta geometria caracteriza o norte da área como um regime de falhamento reverso sinistral.

O domínio Central tem estruturas com direção NS, com a xistosidade subvertical e hospedando a lineação mineral na posição de maior declividade. É caracterizado como um regime de falhamento frontal de alto ângulo, caracterizando escape vertical. Neste domínio a fase $\mathrm{F}_{2}$ está bem caracterizada por dobras $\mathrm{F}_{2}$, que indicam uma tectônica direcional dextral.

O domínio Centro-sul possui estruturas com direções NW, NS e $\mathrm{NE}$, lineação mineral e mullions de dobras, caindo para ENE, condizendo com movimentos reversos dextrais. Este domínio apresenta evidências de partição da deformação $\mathrm{D}_{1}$, entre elas a dispersão da lineação mineral.

O domínio sul apresenta falhas de empurrão com mais baixo ângulo de mergulho, com direção geral NNW, com a lineação mineral oblíqua, revelando regime frontal associado a movimentos laterais sinistrais Trata-se da região de maior encurtamento do sistema. As dobras $\mathrm{F}_{2}$ apresentam a mesma direção e geometria das dobras $\mathrm{F}_{1}$, retratando um continuar da deformação, em caráter coaxial.

Dos dados apresentados, constata-se que, à medida que se afasta para o pós-país, em relação aos obstáculos, as feições decorrentes de particionamento da deformação são atenuadas em mapa. Porém, o fenômeno se manifesta de forma mais sutil. A análise da lapa da Falha da Água Quente mostrou que o particionamento se dá tanto através de movimentos reversos perpendiculares como oblíquos sub-paralelos ao cixo do orógeno. Com o continuar da deformação, a distância dos obstáculos no antepaís torna-se determinante na configuração do escape: tanto maior a proximidade dos obstáculos, maior a tendência é de escape lateral, passando a escape vertical à medida que se afasta dos mesmos. Muitas das feições delineadas nesta abordagem são ainda efeitos da relação autoctonia (embasamento s.s.) versus paraautoctonia (e.g. Maciço do Caraça). De forma bastante simplificada, o que se verifica é que, nos casos de para-autoctonia, as feições de particionamento tendem a se atenuar, porém a exata medida e quantificação desta relação requerem outras metodologias mais sofisticadas de abordagem.

Agradecimentos Agradeço aos professores Issamu Endo do DEGEO-EM-UFOP e Alexandre Uhlein do Departamento de Geociências da UFMG pelas valiosas discussões, sugestōes e críticas ao trabalho. Aos geólogos Luiz Cláudio Ribeiro Rodrigues e Alexandre Cabral pela revisão do texto e pelas sugestões. A SAMITRI, atualmente CVRD, em nome do geólogo Kioshi Kaneko por liberar a entrada $\mathrm{cm}$ algumas minas do Complexo Alegria, além de oferecer apoio logístico. Ao Departamento de Geologia da Universidade Federal de Ouro Preto por todo o apoio logístico. A dois revisores anônimos da RBG pela revisão e sugestões ao original.

\section{Referências}

Alkmim FF. \& Marshak S. 1998. Transamazonian orogeny in the Southern São Franscisco Craton Region. Minas Gerais Brazil: evidence for Paleoproterozoic collision and collapse in the Quadrilátero Ferrífero. Precambrian Research, 90: 29-58.

Almeida F.F.M. 1977. O Cráton do São Francisco. Rè: Bras. Geoc., 7: 349-364.

Alves J.A.C. 1991. Reconstrução estocástica da Mina Säo Luì, Complexo Fazendão. MG. DEGEO. Universidade Federal de Ouro Preto. Dissertação de Mestrado.

Barbosa O. 1954. Évolution du géosynclinal Espinhaço: Internat. Geol. Cong.. 19 th. Algiers 1952. Comptes rendus, sec. 13, pt. 2, fasc. 14, p.: 17-36.

Brueckner H.K., Cunningham W.D., Alkmim F.F., Marshak S. 1999. Tectonic Implications of Precambrian Sm-Nd Dates from the Southern São Francisco Craton and adjacent Araçuaí and Ribeira Belts, Brazil. Precambrian Research (No prelo).

Carneiro M.A. Noce C.M., Teixeira,W. 1995. Evolução policíclica do Quadrilátero Ferrí fero: uma análise fundamentada no conhecimento atual da geocronologia U-Pb e geoquímica Isotópica Sm-Nd. Revista Escola de Minas 48:264-273.

Chemale Jr. F., Rosière C.A., Endo I. 1991. Evolução Tectônica do Quadrilátero Ferrífero, Minas Gerais. Um modelo. Revista Pesquisas, 18:104-127.
Dorr J.V.N. 1969. Physiographic, Stratigraphic and Structural Development of the Quadrilátero Ferrífero, Minas Gerais, Brazil. DNPM/USGS. Prof. Paper. 641-A, p. 110. Mapas e perfis geológicos.

Drake Jr. A.A. \& Morgan B.A. 1980. Precambrian Plate Tectonics in the Brazilian Shield - Evidence from the Pre-Minas rocks of the Quadrilátero Ferrífero, Minas Gerais. USGS Prof. Paper 1119-B, 1-19.

Endo I.. Fonseca M.A.. Gouveia C.G. 1996. Tectônica transcorrente NS de idade Neoarqueana no Quadrilátero Ferrífero. MG. Congresso Brasileiro Geologia. 39. Anais. 1: $437-439$.

Endo I. \& Fonseca M.A. 1992. Sistema de Cisalhamento Fundão - Cambotas no QF. MG geometria e cinemática. Revista Escola de Minas, 45:28-3!

Endo I. \& Nalini Jr. H.A. 1992. Geometria e cinemática das estruturas extensionais c compressionais na borda oeste do Sinclinal Moeda, QF. Revista Escola de Minas 45:15-17.

Endo 1. 1997. Regimes tectônicos do arqueano e proterozóico no interior da Placa Sanfianciscana: Quadrilatero Ferrifero e areas adjacentes, Minas Gerais. IG, USP São Paulo, Tese de Doutoramento, 243 p. 
Ferreira Filho F.A. 1999. Análise Estrutural Qualitutiva do Sistema de Fallas Água Quente Borda Leste do Quadrilatero Ferrifero - MG. Mapa geológico e perfis. DEGEO/ UFOP/EM, Ouro Preto. Dissertação de Mestrado, 162 p.

Harder E.C. \& Chamberlin R.T. 1915. The geology of central Minas Gerais, Brazil. Journat of Geology; 23:341-378,

Herz N. 1970. Gneissic and igneous rocks of Quadrilátero Ferrífero, Minas Gerais, Brazil. USGS/DNPM, Professional Paper 641-B, $57 \mathrm{p}$

Hippert J.F.M., Borba R.P., Nalini Jr. H.A. 1992. O contato Formação Moeda - Complexo Bonfim: Uma zona de cisalhamento normal da borda oeste do Quadrilátero Ferrífero-MG. Revista Escola de Minas, 45:32-34.

Mancktelow N.S. 1992. Neogene lateral extension during convergence in the Central Alps: evidence from interrelated faulting and backfolding around the Simplonpass (Switzerland). Tectonophysics, 215:295-317.

Marshak S. 1988. Kinematics of orocline and arc formation in thin skinned orogens. Tectonics, 7:73-86

Marshak S., Alkmim F.F., Evangelista H. 1992. Proterozoic crustal extension and the generation of dome-and-keel structure in an Archean granite-greenstone terrain. Nature, 357:491-493.

Marshak S., Tinkham D., Alkmim F.F., Brueckner H., Bornhorst, T. 1997. Dome-and-keel provinces formed during Paleoproterozoic orogenia collapse - core complexes, diapirs, or neither ?: Examples from the Quadrilátero Ferrifero and the Penokean orogen. Geology: 25:415-418.

Maxwell C.H. 1972. Geology and Ore Deposits of the Alegria District, MG, Brazil. DNPM/ USGS, Washington, Prof. Paper 341-J, p. 72. Mapas e perfis geológicos.
McClay K.R. 1987. The Mapping of Geological Structures. John Wiley \& Sons. 161p. Nemcok M., Houghton J.J., Coward M.P. 1998. Strain partitioning along the western margin of the Carpatians. Tectonophysics, 292:119-143.

Noce C.M. 1995. Geocnonologia dos eventos magmáticos, sedimentares e metamórficos na regiāo do Quadrilátero Ferrifem, MG. Tese de Doutorado, IG,USP, 128p.

Platt J.P. \& Vissers R.L.M. 1980. Extensional structures in anisotropic rocks. Jour: Struct. Geul., 2:397-410.

Ribeiro Rodrigues L.C. 1992. O contexto geológico-estrutural do Parque Natural do Caraça e adjacências, Quadrilatero Ferrifero, MG. Mapas e perfis. Instituto de Geociências da Universidade de Brasília, Brasília, Dissertação de Mestrado, 109 p.

Schrank A. \& Souza Fillo C.R.de - 1998 - The Tectonic Evolution of the Quadrilátero Fer rifero Region from the Archean to the Neoproterozoic: Revision, Problems and Prospects. In: Abstracts, International Conference on Precambrian and Craton Tectonics. 14th International Conference on Basement Tectonics. Ouro Preto, Brazil, June, 1-5, 1998, p.: 122-125.

Vauchez A., Babaei H.A., Babaei A. 1993. Orogen-parallel tangential motion in the Late Devonian-Carboniferous southern Appalachians internides. Can.J. Earth Sci., 30:1297-1305.

Manuscrito A-1168

Recebido em 20 de junho de 2000 Revisão dos autores em 15 de setembro de 2001 Revisão accita em 20 de setembro de 2001 